\title{
Green synthesis of zinc oxide nanoparticles and zinc oxide-silver, zinc oxide-copper nanocomposites using Bridelia ferruginea as biotemplate
}

\author{
E. Gurgur ${ }^{1}$ (D) S. S. Oluyamo² $\cdot$ A. O. Adetuyi ${ }^{1} \cdot$ O. I. Omotunde ${ }^{3} \cdot$ A. E. Okoronkwo ${ }^{1}$
}

Received: 28 November 2019 / Accepted: 17 February 2020 / Published online: 16 April 2020

(c) Springer Nature Switzerland AG 2020

\begin{abstract}
The quest to synthesize nanomaterials with improved properties, but less undesirable effects on the environment necessitated this research. Zinc Oxide ( $\mathrm{ZnO}$ ) nanoparticles and zinc oxide-silver ( $\mathrm{ZnO}-\mathrm{Ag})$, zinc oxide-copper ( $\mathrm{ZnO}-\mathrm{Cu}$ ) nanocomposites were synthesized with pure eco-friendly dye extracted from Bridelia ferruginea, zinc acetate $\left(\mathrm{Zn}\left(\mathrm{CH}_{3} \mathrm{COO}_{2}\right)\right.$ as host, copper acetate $\left(\mathrm{Cu}\left(\mathrm{CH}_{3} \mathrm{COO}\right)_{2}\right)$, and silver nitrate $\left(\mathrm{AgNO}_{3}\right)$ as dopant precursors. Phytochemical screening of dyes showed high, presence of phenols and terpenoids. The nanomaterials were characterized by Fourier-transform infrared, $\mathrm{X}$-ray diffraction, scanning electron microscopy with energy dispersive X-ray analysis, transmission electron microscopy and ultraviolet-visible spectroscopy. The results showed the capping agents in the dyes were responsible for reducing the bulk materials. The crystallinity of the nanomaterials were found to be $19.02,18.98$ and $18.90 \mathrm{~nm}$ for the $\mathrm{ZnO}, \mathrm{ZnO}-\mathrm{Ag}$ and $\mathrm{ZnO}-\mathrm{Cu}$ nanoparticles respectively. The $\mathrm{ZnO}$ nanoparticles were flakelike in shape, whereas the $\mathrm{Cu}$ and $\mathrm{Ag}$ doped particles were spherical. An optical bandgap of $4.73 \mathrm{eV}$ was recorded for the dye and $3.24 \mathrm{eV}$ for the $\mathrm{ZnO}$ nanoparticles. This was narrowed to 3.18 and $3.13 \mathrm{eV}$ by silver and copper dopant respectively. These results showed the nanoparticles as a potential agent for photovoltaics and other optical applications.
\end{abstract}

Keywords Bridelia ferruginea · Green synthesis · Nanoparticles · Nanocomposites · Dye

\section{Introduction}

Nanoscience and nanotechnology are divest fields that modify bulk materials and improve their optical, electronic, magnetic, and catalytic properties [1], these properties are targeted at improving human lives. As global warming has ravaged the universe, the world scientists are trying hard to open new doors to finding novel technologies in the development of new materials with unique characteristics [2] but of low environmental hazard. The known two types of nanomaterials are the organic and inorganic nanoparticles. The former being poly- $\varepsilon$-lysine, quaternary ammonium compounds, cationic quaternary polyelectrolytes, and Chitosan. The latter being mainly oxides of silver (Ag), iron (Fe), titanium (Ti), copper ( $\mathrm{Cu})$, zinc $(\mathrm{Zn})$ and other transition element. The stability of the inorganic particles at variable temperature gave it a wide range of industrial applications [3, 4]. Metallic nanoparticles are synthesized by different techniques; the more frequently employed methods are the chemical and physical methods. Several chemical methods had been identified, but researchers work more on chemical reduction, electrochemical techniques, and photochemical reactions in synthesizing and modifying nanomaterials $[1,3,5]$. The attrition and pyrolysis techniques took center stage under physical method, although the technique is brand as wasteful due to its

$\triangle$ E. Gurgur, tgurgur24@gmail.com| ${ }^{1}$ Department of Chemistry, The Federal University of Technology, Akure, Ondo, Nigeria. ${ }^{2}$ Department of Physics, The Federal University of Technology, Akure, Ondo, Nigeria. ${ }^{3}$ Department of Chemistry Education, The Federal University, Oye, Ekiti, Nigeria. 
high cost, high-energy consumption and low output rate $[3,6]$. The consciousness of environmental deterioration has cautioned scientists to look towards greener approach which is an inexpensive nontoxic approach in synthesizing and fabricating nanomaterials [1]. Recently extracts of unicellular organisms, as well as plants have recorded tremendous success in the synthesis of nanoparticles of different shapes and sizes [7]. However, synthesis of nanomaterials using microorganisms is arduous because of the complex and complicated nature of isolating, maintaining cell cultures and multiple purification steps. Hence, it is advisable to synthesize nanoparticles using plant materials due to their availability and the procedure of biogenic synthesis is cost efficient, less tedious as compared to biosynthesis using fungal sources [8]. Several metal oxide nanoparticles had been produced with possible industrial applications. Among these, $\mathrm{ZnO}$ is the most exploited at nano-dimensions because of its exceptional scientific properties attributed to its band gap and large excitonic binding energy [9]. It has become a focal point of nowadays research considering its tremendous antimicrobial activity against a wide range of microorganisms. S. aureus, E. coli, Salmonella, Listeria monocytogenes, and the fungus Fusarium [10, 11]. Doping ZnO nanoparticles with Copper, Cobalt, Nickel, rare earth metals, and transition elements, as impurities modified the nanoparticles to enhance their electrical, optical and biological activities [12-14]. Silver and Copper doped $\mathrm{ZnO}$ nanoparticles have gained great interest in growing a full scope of innovative applications including field effect transistors, field emission arrays, ultraviolet lasers, light emitting diode, sensors, biosensors, catalyst, energy storage and solar cell $[15,16]$.

In recent times nanomaterials are synthesized with templates which are perceived easy with simplified procedures to give room for better fabrication of more sophisticated nanomaterials [17]. Templates are categorized into two groups of soft and hard. Porous solids like anodic aluminium oxide (AAO) membranes, colloid beads, ordered mesoporous inorganic materials, and zeolites are regarded as hard templates. Soft templates are organic molecules, long-chain polymers, supermolecular aggregates, structure-directing agents, surfactants, gels, micelles, and different types of biological species (biotemplates). Soft templates did not only render more sufficient synthetic processes, but also have the ability to be easily removed, these have proven their effectiveness and shown their ability in high quality encapsulation techniques $[18,19]$. Dyes were believed to be substances that only impact colour to textiles, sequel to the dominance of synthetic dyes. But with the arrival of natural dyes, their benefits and values have been appreciated in all areas of life, especially in natural medicine, food and recently nanotechnology [20]. Natural dyes are usually not a single entity, but a variety of closely related chemical compounds, which enhance their therapeutic roles in natural medicine, impact colour to fabrics, reduce and cap ions in nanoscience. The complex chemical constituents in natural dyes are Anthraquinones, Naphthoquinones, Benzoquinones, Flavonoids, Carotenoids and Tannins [21]. Synthesis of nanoparticles by solvent extracted dyes from $B$. ferruginea is sparingly reported, implying the plant is underexploited on nanodimension. This motivated our interest in this research. Our focus is to extract dyes from $B$. ferruginea that belongs to the family Euphorbiaceae and found mostly in Savannah regions. It has dark grey, rough and oftentimes marked scaly bark [22]. The plant is a major actor in traditional medicine; with its extract playing a significant role in the formulation of a traditional gargle "egun efu" and water treatment [23]. A handful of reports on the bark extract has proven its high anti-typanocidal, anti-molluscidal, antimicrobial and anti-inflammatory properties [24]. The leaves also demonstrated curative effecst towards the treatment of diabetes and as a purgative. $[25,26]$. The curative strength of $B$. ferruginea has been attributed to its high antioxidants and phytochemicals, hence it can serve as an excellent agent in the reduction of $\mathrm{Zn}\left(\mathrm{CH}_{3} \mathrm{COO}\right)_{2}$, $\mathrm{Cu}$ $\left(\mathrm{CH}_{3} \mathrm{COO}\right)_{2}$ and $\mathrm{AgNO}_{3}$ to their nanoparticles and nanocomposites, as well as capped the ions to their states.

\section{Materials and methods}

\subsection{Chemicals}

The following chemicals $\mathrm{Zn}\left(\mathrm{CH}_{3} \mathrm{COO}\right)_{2}, \mathrm{Cu}\left(\mathrm{CH}_{3} \mathrm{COO}\right)_{2}$, $\mathrm{AgNO}_{3}, \mathrm{n}$-hexane and methanol were obtained from Sigma-Aldrich and used without further purification. All solutions were prepared with deionize water.

\subsection{Sample collection and preparation}

The bark of Bridelia ferruginea used as the source of the dye was collected from a farmland at Ido Usi, Ekiti State of Nigeria, Sun dried, ground, sieved to have uniformed particles and were stored in an airtight container for the extraction of the dye.

\subsection{Extraction of dye}

Soxhlet apparatus was used for the extraction of dyes. The Pulverized sample was loaded in the thimble and mounted on the round bottom flask. The sample was first defatted with $\mathrm{n}$-Hexane for $6 \mathrm{~h}$ at a heating rate of $68^{\circ} \mathrm{C}$. The defatted samples were offloaded from the thimble, sundried to remove the trapped $n$-hexane and reloaded for the dyes 
extraction using methanol at the heating rate of $65^{\circ} \mathrm{C}$. The dyes were oven dried at $40^{\circ} \mathrm{C}$ to powder.

\subsection{Green synthesis of nanoparticles and nanocomposites}

The nanoparticles were synthesized using green synthesis method as reported by Yedurkar et al, [27], with the exclusion of $\mathrm{NaOH}$ that acted as a pH stabilizing agent. $10 \mathrm{~g}$ of the dye was dissolved in $100 \mathrm{ml}$ of methanol, filtered with Whatman filter paper to remove any undissolved particles. $50 \mathrm{ml}$ of the dye's filtrate was added $100 \mathrm{ml}(0.5 \mathrm{M})$ of $\mathrm{Zn}\left(\mathrm{CH}_{3} \mathrm{COO}\right)_{2}$ was allowed to stand for $2 \mathrm{~h}$ at room temperature. The initial light brown colouration of the solution became a deep brown crowded solution indicating the complete formation of the precipitate. This affirmed the reduction of zinc acetate to zinc oxide nanoparticles. The mixture was stirred for $1 \mathrm{~h}$, centrifuged for $30 \mathrm{~min}$ and washed severally with deionized water and ethanol. The pure reduced $\mathrm{ZnO}$ nanoparticles were oven dried at $80^{\circ} \mathrm{C}$ for $6 \mathrm{~h}$ and calcined at $500^{\circ} \mathrm{C}$ for $1 \mathrm{~h}$. The nanocomposites were synthesized by mixing $100 \mathrm{ml}(0.5 \mathrm{M})$ of $\mathrm{Zn}\left(\mathrm{CH}_{3} \mathrm{COO}\right)_{2}$ with $100 \mathrm{ml}(0.05 \mathrm{M})$ of $\mathrm{AgNO}_{3}$ or $\mathrm{Cu}\left(\mathrm{CH}_{3} \mathrm{COO}\right)_{2}$ for the synthesis of $\mathrm{ZnO}-\mathrm{Ag}$ and $\mathrm{ZnO}-\mathrm{Cu}$ respectively. The solution was stirred for 2 min on a magnetic stirrer and the methanolic extract of the dye was added to the mixture. The finishing protocol for $\mathrm{ZnO}$ was adopted for the composites. Figure 1 presents a schematic representation of the synthetic pathway for the particles (Scheme 1).

\subsubsection{Reaction mechanism for the synthesis of $\mathrm{ZnO}$ nanparticle and $\mathrm{ZnO}-\mathrm{Ag}$ nanocomposite}

The presence of tannins, terpenoid and flavonoids in the dye extract which behave as ligands and their special ability to chelate various metal ions enhance the reduction
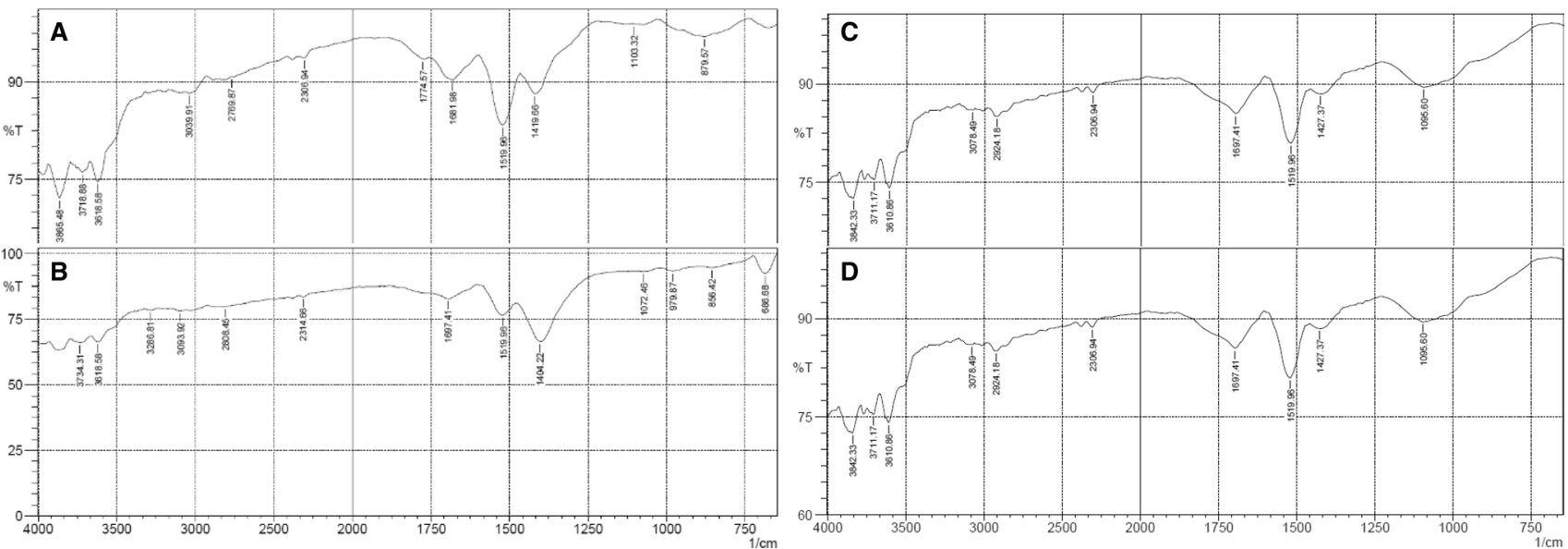

Fig. 1 FTIR of a ZnO Nanoparticle b ZnO-Ag Nanocomposite c ZnO-Cu Nanocomposite d dye of B. ferruginea

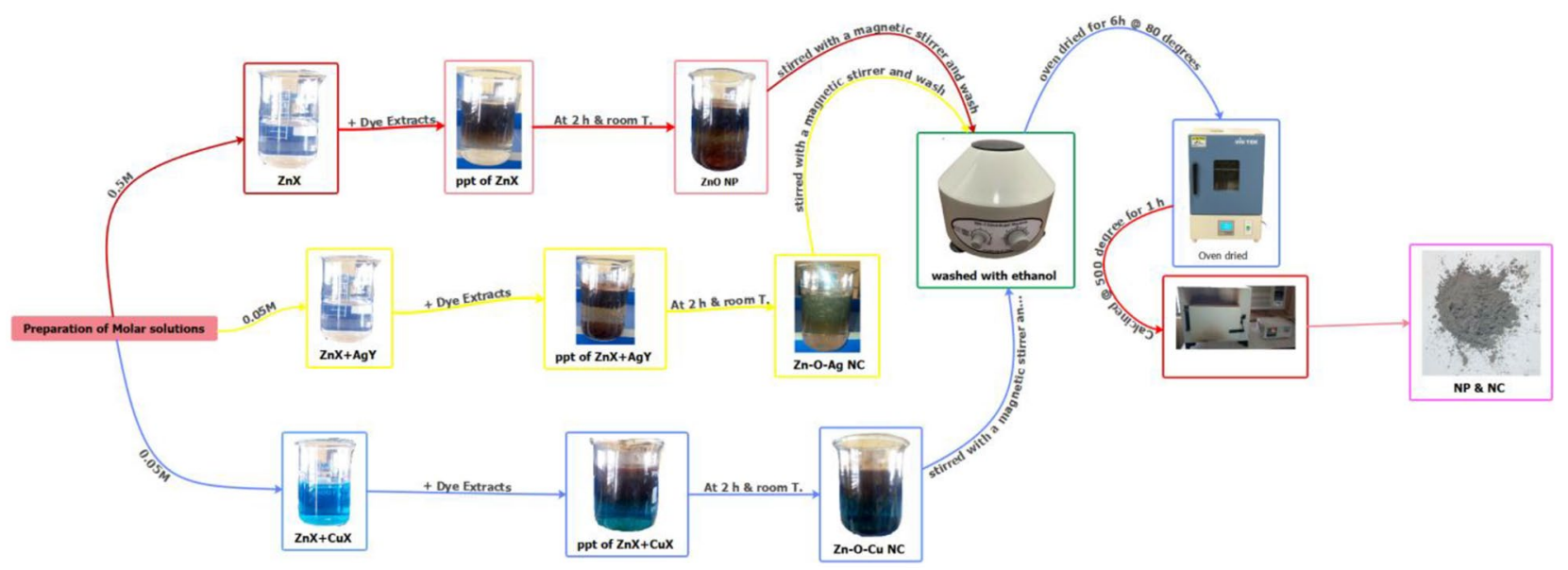

Scheme 1 Schematic representation of the synthetic pathway of $\mathrm{ZnO}$ nanoparticles (NP) and ZnO-Ag and ZnO-Cu nanocomposite 
and subsequent stabilization of the ions to their nano form. Among the phytochemical constituents, flavonoids readily chelate metal ions and create complex compounds due to their ability to donate electrons and hydrogen atoms. Zinc acetate, Copper acetate and silver trioxonitrate (V) dissolved in water to become freely moving ions as shown in the Eqs. (1 and 2) for Zinc acetate.

$\mathrm{Zn}\left(\mathrm{CH}_{3} \mathrm{COO}\right)_{2} \rightarrow \mathrm{H}_{3} \mathrm{C}-\mathrm{CO}_{2}^{-} \mathrm{Zn}^{2+}$

$\mathrm{H}_{3} \mathrm{CO}_{2}^{-} \mathrm{Zn}^{2+} \stackrel{\mathrm{H}_{2} \mathrm{O}}{\longrightarrow} \mathrm{H}_{3} \mathrm{C}-\mathrm{CO}_{2}^{-}+\mathrm{Zn}^{2+}$

The free ions attack the active sites on the phenolic compound present in the dye extract to gain stability hence, reducing it to its nano form. The large number of "OH" functional groups in phytochemical is a major factor in the reduction process. This factor favours the formation of a hydrophilic surfaces arising from the dissolved oxygen (from air) molecules, that are suitable for the growth of nanoparticles [28]. The Mechanism pathway for the synthesis of $\mathrm{ZnO}-\mathrm{Ag}$ nanocomposite is the same as $\mathrm{ZnO}-\mathrm{Cu}$ nanocoposite synthesis (Scheme 2).

\subsection{Phytochemical analysis of the dye}

Phytochemical screening was performed on the dye to ascertain the presence of reducing and capping agent present in the dye extracts. The assays to investigate are; tannins, steroids, phlobatannins, saponins, flavornoids, phenols, anthocyanins and terpenoids and using established methods [30-32, 33].

\subsubsection{Test for tannin}

$10 \mathrm{ml}$ of bromine water was added to the $0.5 \mathrm{~g}$ aqueous extract. Decoloration of bromine water comfirmed the presence of tannins

\subsubsection{Test for steroids}

$2 \mathrm{ml}$ of chloroform and concentrated $\mathrm{H} 2 \mathrm{SO} 4$ were added with the $5 \mathrm{ml}$ aqueous plant crude extract. In the lower chloroform layer red color appeared that indicated the presence of steroids

\subsubsection{Test for phlobatainin}

$1 \%$ aqueous $\mathrm{HCl}$ acid was added to $5 \mathrm{ml}$ of the extract, it was then boiled with the help of Hot plate stirrer. The absence of a red precipitate was evidence for the absent of phlobatannins in this sample.

\subsubsection{Test for saponins}

$5.0 \mathrm{ml}$ of distilled water was vigorously mixed with aqueous crude plant extract in a test tube. Few drops of olive oil was added to the mixture upon froth appearance and vigorously mixed. The appearance of foam confirmed the presence of saponins.

\subsubsection{Test for flavonoids}

Alkaline Reagent Test were used to confirm the presence of flavonoids in bark of B. ferruginea. $2 \mathrm{ml}$ of $2.0 \% \mathrm{NaOH}$ mixture was mixed with crude aqueous extract of the plant; concentrated yellow color was produced, which became colorless when 2 drops of diluted acid was added to the mixture. This result showed the presence of flavonoids.

\subsubsection{Test for phenol}

$5 \mathrm{ml}$ of the methanolic plant extract was mixed with $2 \mathrm{ml}$ of $2 \% \mathrm{FeCl}_{3}$ solution. A blue-green or black coloration indicated the presence of phenols

\subsubsection{Test for cyanogenic glycoside}

Sodium picrate test or Guignard reaction was used to confirm the presence of anthocyanins. A soaked filter paper strips was first in $10 \%$ picric acid and then in $10 \%$ sodium carbonate and dried. The extracts were taken in small bottles and the strips were suspended from the mouth of the container and the lids were tightly closed with portion of the $s$ trip stuck in the lid. The strips did not turn brick red nor maroon indicating the absence of cyanogenic glycosides (anthocyanins)

\subsubsection{Test for terpenoids}

Chloroform (2 $\mathrm{ml})$ was added to aqueous plant extract $(5 \mathrm{ml})$ and evaporated on a water bath and then boiled with $3 \mathrm{ml}$ of concentrated $\mathrm{H} 2 \mathrm{SO} 4$. A grey coloration attests to the presence of terpenoids.

\subsection{Characterization of biosynthesized ZnO nanoparticles and ZnO nanocomposite of Silver or Copper}

The FTIR (Shimadzu Co. Ltd., Kyoto, Japan) was used with $\mathrm{KBr}$ pellets in the wavelength range $4000-500 \mathrm{~cm}^{-1}$ for identification of the functional groups involved in the reduction of the precursors to nanoparticles and nanocomposites. The phase formation, purity and crystallinity of the nanoparticles were recorded using XRD (GBC eMMA). The visual properties of $\mathrm{ZnO}$ nanoparticles 
A<smiles>O=C1c2c(O)cccc2OC(c2ccc(O)c(O)c2)C1O</smiles>

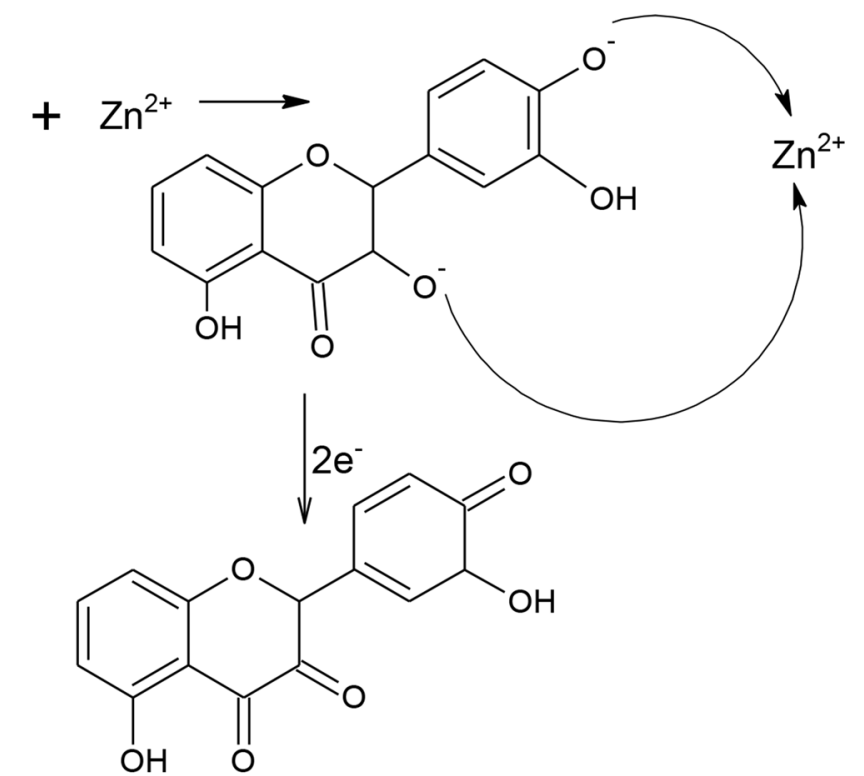<smiles>[R]OC1C(=O)c2c(O)cc(O)cc2OC1c1ccc(O)c(O)c1</smiles>

Scheme 2 Schematic mechanism for the synthesis of a ZnO Nanoparticles and $\mathbf{b}$ ZnO-Ag nanocomposite (Idea from work of Ahmad et al. [29] and Mohammed et al. [28])

and nanocomposites were investigated, based on UV-Vis absorption spectra in the wavelength range of 200-800 $\mathrm{nm}$. The morphologies, elemental composition and particle size were investigated using SEM equipped with an EDX (Quanta 200-FEl coupled to EDS probe) and TEM (TECNAI G2 SPIRIT-FEI). 


\section{Results and discussion}

\subsection{Phytochemical analysis}

The methanolic dye extract was screened for major phytochemicals as shown in Table 1. Aside the biological and the therapeutic properties, the metabolites are reported to have excellent reducing and stabilizing ability towards the reduction of bulk metals to the nano forms [34]. High extract yields of phenols and terpenoids were recorded in the dye. This is ascribed to the high polarity of methanol solvent to a variety of plant constituents [31]. The presence of these molecules gives the dyes the expected self-assemblage and ability to cap the metal nanoparticles formed, thereby inducing controlled morphology [35].

Among the metabolites, terpenoids and phenols isolated from plants are implicated in successfully catalyzing the reduction of bulk material to nano ions [30, 34]. The ability of phenol to act as capping agent lies in the presence of hydroxyl and carboxylic group which makes it a good chelator [36], impacting it with ability to stabilize metal ions [37]. The presence of the two metabolites gave the dye the expected strength to reduce bulk materials and stabilize the metal ions. The absence of anthocyanine confirmed report in literatures that, it can only exist in storage tissues of the plants [38].

\subsection{FTIR spectroscopy of the synthesized nanoparticles and nanocomposites}

FTIR (Fig. 1) was used to identify the possible functional groups that are actively involved in the reduction of $\mathrm{Zn}\left(\mathrm{CH}_{3} \mathrm{COO}\right)_{2}, \mathrm{AgNO}_{3}$ and $\mathrm{Cu}\left(\mathrm{CH}_{3} \mathrm{COO}\right)_{2}$ to various nanoparticles and nanocomposite. A broad peak at $3394.83 \mathrm{~cm}^{-1}$ for $B$. ferruginea dyes is assigned hydrogen $\mathrm{O}-\mathrm{H}$ band stretching, but shifted to $3618.58 \mathrm{~cm}^{-1}$ on the spectra of $\mathrm{ZnO}$ nanoparticles, $\mathrm{ZnO}-\mathrm{Ag}$ and $\mathrm{ZnO}-\mathrm{Cu}$ nanocomposites [39]. The dyes have a crest at $1635.69 \mathrm{~cm}^{-1}$

Table 1 Phytochemical constituents of Bridelia ferruginea

\begin{tabular}{|c|c|c|c|c|}
\hline Phytochemical test & Absent & present & $\begin{array}{l}\text { Slightly } \\
\text { present }\end{array}$ & Heavily present \\
\hline Tannin & & & ++ & \\
\hline Steroids & & & ++ & \\
\hline Phlobatainins & & + & & \\
\hline Sapoins & & + & & \\
\hline Flavonoids & & + & & \\
\hline Phenols & & & & +++ \\
\hline Anthocyanins & - & & & \\
\hline Terpenoids & & & & +++ \\
\hline
\end{tabular}

which is characteristic of aldehydes $\mathrm{C}=\mathrm{O}$ stretches, but slightly moved to higher frequencies on the spectra of $\mathrm{ZnO}$ nanoparticles, $\mathrm{ZnO}-\mathrm{Ag}$ and $\mathrm{ZnO}-\mathrm{Cu}$ nanocomposite. A H-C-H asymmetric and symmetric stretch peak was found at $2931 \mathrm{~cm}^{-1}$ on the dye's spectrum, but at $2924.18 \mathrm{~cm}^{-1}$ for $\mathrm{ZnO}-\mathrm{Cu}$ and $2808.92 \mathrm{~cm}^{-1}$ for $\mathrm{ZnO}$-Ag nanocomposites. The peak at $1527 \mathrm{~cm}^{-1}$ on the dye spectra is for $\mathrm{N}-\mathrm{H}$ bends. This however appears as $\mathrm{N}-\mathrm{H}$ stretching at $3286 \mathrm{~cm}^{-1}$ for $\mathrm{ZnO}-\mathrm{Ag}$. The spectral bands at $1419.66 \mathrm{~cm}^{-1}, 1427.37 \mathrm{~cm}^{-1}$ and $1450.52 \mathrm{~cm}^{-1}$ confirmed the presence of $\mathrm{C}-\mathrm{H}$ bending, while $1103.32 \mathrm{~cm}^{-1}$, $1072.46 \mathrm{~cm}^{-1}, 1095.60 \mathrm{~cm}^{-1}$ correspond to C-O stretching for $\mathrm{ZnO}, \mathrm{ZnO}-\mathrm{Ag}, \mathrm{ZnO}-\mathrm{Cu}$ respectively. The crest at $1411.94 \mathrm{~cm}^{-1}$ on the FTIR spectra of the dyes is typical of $\mathrm{S}=\mathrm{O}$ stretching, but this appeared on a lowered frequency of $1404.22 \mathrm{~cm}^{-1}$ on $\mathrm{ZnO}-\mathrm{Ag}$ nanocomposite. The functional groups between 686.68 and $879.57 \mathrm{~cm}^{-1}$ correlates to metal oxide bands [5].

The absence of $\mathrm{S}=\mathrm{O}, \mathrm{N}-\mathrm{H}$ bends, $\mathrm{H}-\mathrm{C}-\mathrm{H}$ asymmetric and symmetric bands on the spectra of $\mathrm{ZnO}$ nanoparticles and $\mathrm{ZnO}-\mathrm{Cu}$ nanocomposite spectra confirmed that the functional groups were used up in the reduction of the zinc acetate and Copper acetate [40]. All the band and functional groups identified are peculiar to the phytoconstituents identified in the phytochemical screening [41].

\subsection{UV-visible spectroscopy}

Figure 2 presents the UV-Vis absorption spectra of $\mathrm{ZnO}$ nanoparticles, $\mathrm{ZnO}-\mathrm{Ag}$ and $\mathrm{ZnO}-\mathrm{Cu}$ nanocomposites and the dye. There is an excitonic peak between $206 \mathrm{~nm}$ for the dyes and $251 \mathrm{~nm}$ for the $\mathrm{ZnO}-\mathrm{Ag}$, these peaks are characteristic of the polyphenolic compounds which acted actively during the synthetic and reduction processes between the phyto-compounds of $B$. ferruginea, and metal precursors [42]. These peaks also pointed to presence of $\mathrm{ZnO}$ nanoparticles, which lies much below the bandgap wavelength [41]. Peaks between 300 and $400 \mathrm{~nm}$ are characteristic of $\mathrm{ZnO}$ nanoparticles which may be due to the electron transition from the valence band to the conduction band. The appearance of distinctive peaks of low absorption intensity on the spectra of $\mathrm{ZnO}$ nanoparticles, $\mathrm{ZnO}-\mathrm{Ag}$ and $\mathrm{ZnO}-\mathrm{Cu}$ nanocomposite between 320 and $360 \mathrm{~nm}$ confirmed the formation of $\mathrm{ZnO}$ nanoparticles [43]. The reduction in the peak intensity in the spectra of the $\mathrm{ZnO}-\mathrm{Ag}$ and $\mathrm{ZnO}-\mathrm{Cu}$ indicated the inclusion of $\mathrm{Ag}^{2+}$ and $\mathrm{Cu}^{2+}$ in the matrix of the nanocomposites and suggested some level of agglomeration with irregular shapes [44]. The region of absorption of the spectrum suggested the suitability of the nanomaterials for both UV and visible region [45]. 
Fig. 2 UV-Vis Absorption spectroscopy of $\mathrm{ZnO}$ nanoparticles, ZnO-Ag nanocomposite, $\mathrm{ZnO}-$ Cu nanoparticles and dyes

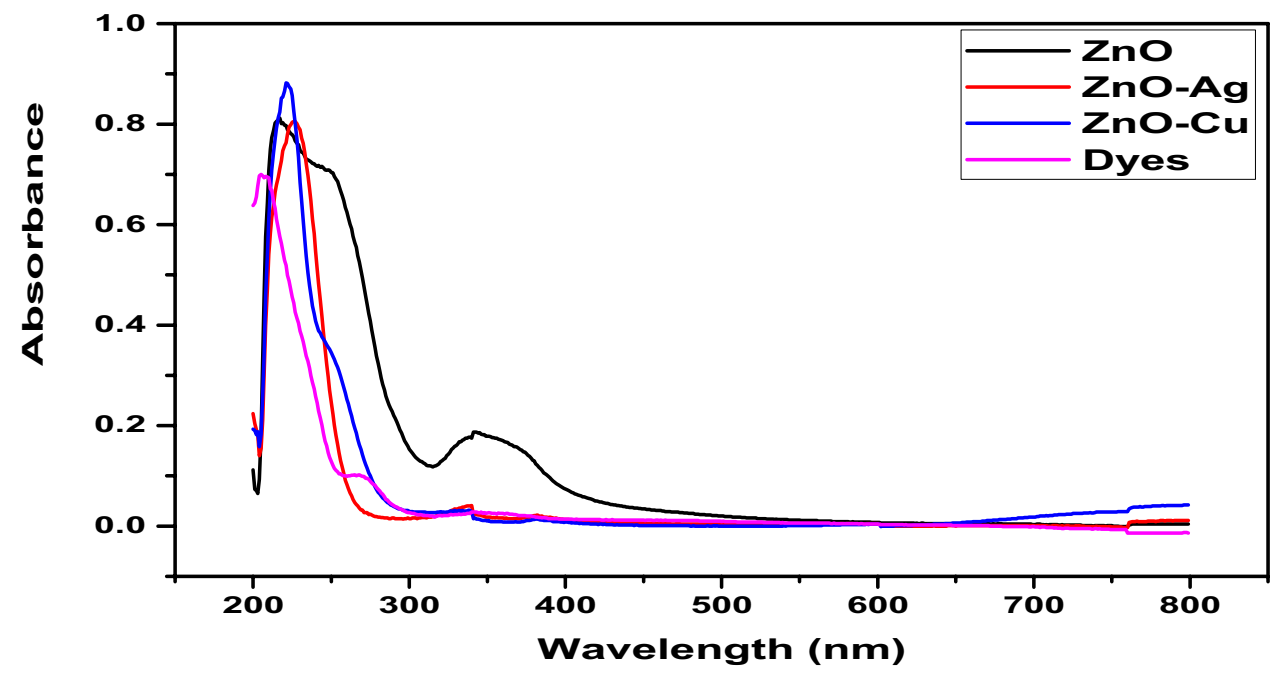

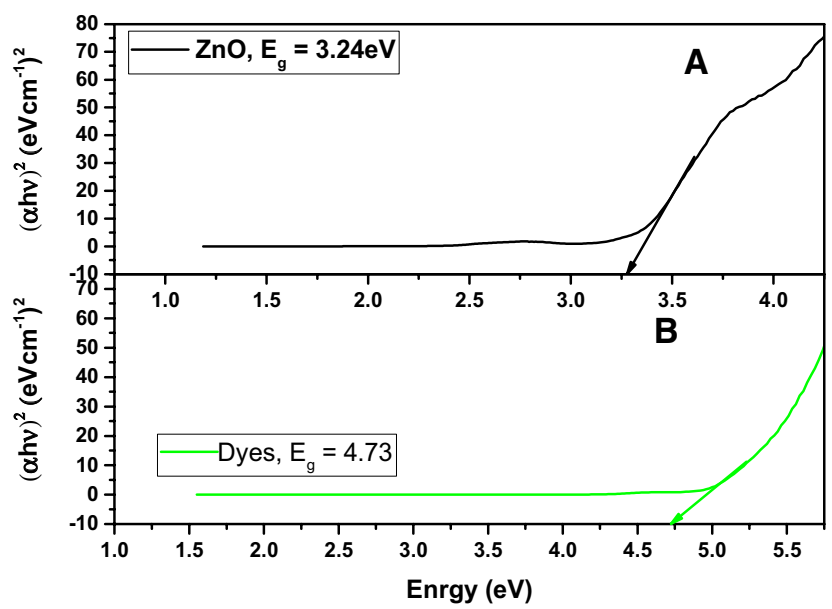

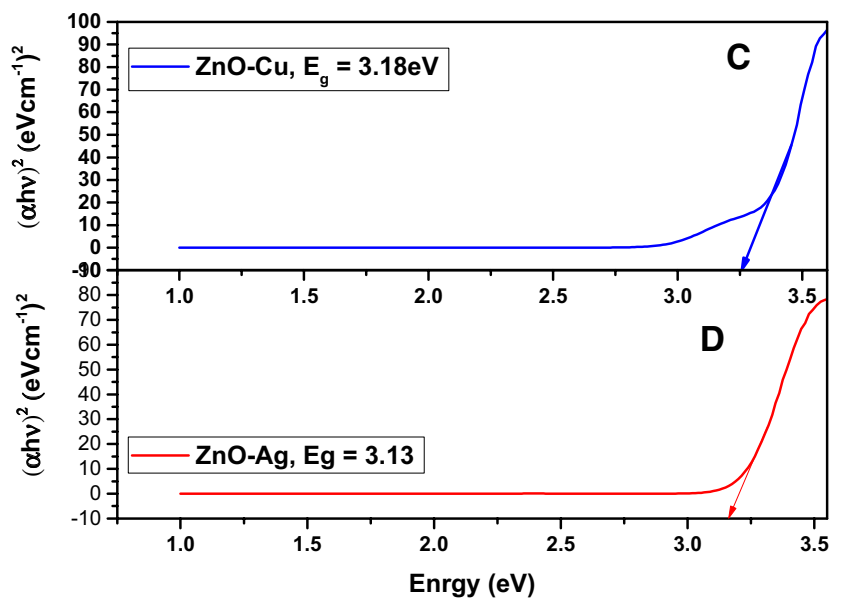

Fig. 3 Tauc's plot for optical band gap of a ZnO nanoparticles, b dyes, $\mathbf{c} \mathrm{ZnO}-\mathrm{Cu}$ nanocomposite and $\mathbf{d}$ ZnO-Ag nanocomposite

The optical band gap (Fig. 3), was estimated using Tauc's plot for direct transition semiconductor, by extrapolating the straight line of $(a h v)^{2}$ versus hv graph. High band gap energy of $4.73 \mathrm{eV}$ is recorded for the dye, but was reduced to $3.24 \mathrm{eV}$ in $\mathrm{ZnO}$ nanoparticles. The introduction of $\mathrm{Ag}$ and $\mathrm{Cu}$ impurities in the nanocomposite narrowed the band gap to $3.18 \mathrm{eV}$ and $3.12 \mathrm{eV}$ for $\mathrm{ZnO}-\mathrm{Cu}$ and $\mathrm{ZnO}-\mathrm{Ag}$ respectively.

This narrowing of band gap became prominent as $\mathrm{Zn}^{2+}$ is gradually substituted by $\mathrm{Cu}^{2+}$ and $\mathrm{Ag}^{2+}$ in the matrix of the materials and systematically increased the number of oxygen vacancies due to their ion radii and electronegativity [46]. More so, the impurities created a special defect, which simulates the Fermi level to rise towards the conduction $[41,45,47,48]$

Figure 4 is the XRD diffractogram of $\mathrm{ZnO}$ nanoparticle, $\mathrm{ZnO}-\mathrm{Ag}$ and $\mathrm{ZnO}-\mathrm{Cu}$ nanocomposites. The peaks at
$2 \theta$ of $31.62^{\circ}, 34.30^{\circ}, 36.11^{\circ}, 47.41^{\circ}, 56.47^{\circ}, 62.75^{\circ}, 67.83^{\circ}$ and $68.95^{\circ}$ for $\mathrm{ZnO}$ nanoparticles diffractogram lie in the crystallographic planes of (100), (001), (101), (102), (110), (103), (112) and (201). These agree with standard JCPDS card No. 89-0510, and correspond to the Hexagonal wurtzite $[42,49-51]$. The crystallography of $\mathrm{ZnO}-\mathrm{Ag}$ showed peaks that correspond to $2 \theta$ values $26.84^{\circ}, 29.46^{\circ}, 31.95^{\circ}$, $44.96^{\circ}, 47.42^{\circ}, 50.89^{\circ}, 53.33^{\circ}, 56.28^{\circ}, 63.45^{\circ}$ and $68.82^{\circ}$ and within the crystallographic planes of (111), (111), (200), (220), (220), (311), (222), (311), (400) and (331). These are concordant with JCPDS No. 89-4937. The peaks at $26.84^{\circ}$, $29.46^{\circ}$ and $31.95^{\circ}$ are due to the presence of bio-organic phases on the surface of the particles [44], these would have been contributed by the polyphenolic compounds. Characteristic peaks of $\mathrm{Ag}^{+}$signal appeared at $2 \theta 4.96^{\circ}$ and $63.45^{\circ}$. This attest to the presence of $\mathrm{Ag}^{+}$in the $\mathrm{ZnO}-\mathrm{Ag}$ nanocomposite. A similar diffractogram was reported by 


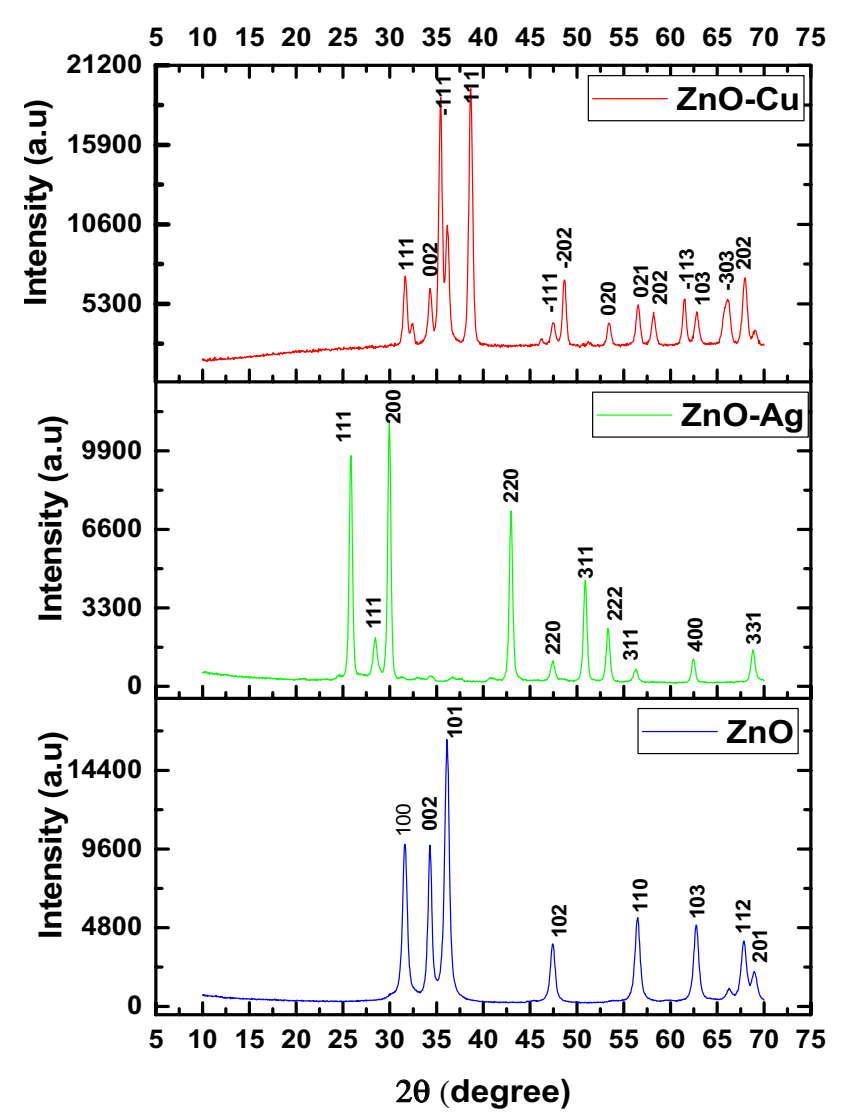

Fig. 4 The X-ray Diffraction of a $\mathrm{ZnO}$ nanoparticle $\mathbf{b} \mathrm{ZnO}-\mathrm{Ag}$ and $\mathbf{c}$ ZnO-Cu nanocomposite

Dinesha et al.,when he dope $\mathrm{ZnO}$ with $\mathrm{Ag}$ [52]. However, there is an overlap of $\mathrm{Ag}^{+}$signals with the wurtzite plane at (311), (400) and (331). The influence of doped Ag onto $\mathrm{ZnO}$ significantly altered the peak orientation, due to replacement of $\mathrm{Ag}^{+}$into host $\mathrm{ZnO}$ crystal lattice [53]. All the other peaks confirmed in the XRD graph of $\mathrm{ZnO}-\mathrm{Ag}$ nanocomposite are assigned to $\mathrm{ZnO}$ nanoparticles. The diffractograms of $\mathrm{ZnO}-\mathrm{Cu}$ nanoparticles show peaks in the crystallographic plan of (002) and (101) which are typical of $\mathrm{ZnO}$ nanoparticles. The crystallographic peaks of $2 \theta$ at $35.55^{\circ}, 38.65^{\circ}, 47.47^{\circ}, 48.66^{\circ}$ lies in the plane of $(-111),(1$ $11),(-202)$. These are in consonance with the XRD pattern, with the presence of copper doped on the $\mathrm{ZnO}$ [3]. There is an overlapping of the $\mathrm{Cu}$ and $\mathrm{Zn}$ signals, especially at a $2 \theta$ value of $62.81^{\circ}, 66.02^{\circ}$ and $67.95^{\circ}$. The extra peaks are plant phytoconstituents which probably escaped the washing of $\mathrm{ZnO}-\mathrm{Ag}$ during the synthesis.

The Highly absorbed diffraction peaks confirmed the significant crystallinity of $\mathrm{ZnO}, \mathrm{ZnO}-\mathrm{Ag}$ and $\mathrm{ZnO}-\mathrm{Cu}$ nanomaterials. The unavailability of other diffracted peaks on the diffractogram of $\mathrm{ZnO}$ and $\mathrm{ZnO}-\mathrm{Ag}$ authenticates the high purity of the synthesized $\mathrm{ZnO}$ nanoparticles [7, 41]. The decrease in peak's intensity on the $\mathrm{ZnO}-\mathrm{Ag}$ and
$\mathrm{ZnO}-\mathrm{Cu}$ diffractograms, is a behavioural pattern peculiar to decreased crystallite sizes in the presence of the dopant. There is a slight shift on the $\mathrm{ZnO}$ peaks accounting for the present $\mathrm{AgO}$ and $\mathrm{CuO}$ fussed in the $\mathrm{ZnO}$ wurtzite lattice. The secondary phase of $\mathrm{AgO}$ and $\mathrm{CuO}$ diffraction peaks indicated the formation of $\mathrm{AgO}-\mathrm{ZnO}$ and $\mathrm{CuO}-\mathrm{ZnO}$ nanocomposite. The change in the crystallite size and a shift on $\mathrm{ZnO}$ on the diffractogram is the confirmation of the presence of $\mathrm{Ag}$ and $\mathrm{Cu}$ incorporated into the $\mathrm{Zn}$ site $[3,17,54]$.

The average grain size of the sample, was calculated using the Debye Scherer's equation

$D=\frac{0.9 \lambda}{\beta \cos \theta}$

where $D$ is Crystal size (nm), is the wavelength of the XRD used, is FWHM, and is Bragg's angle [40, 45, 55]. X-ray diffractogram was analyzed to obtain information about various crystalline aspects of $\mathrm{ZnO}$ nanoparticle, $\mathrm{ZnO}-\mathrm{Ag}$ and $\mathrm{ZnO}-\mathrm{Cu}$ nanocomposite materials. The average crystallite size of $\mathrm{ZnO}, \mathrm{ZnO}-\mathrm{Ag}$ and $\mathrm{ZnO}-\mathrm{Cu}$ is about $19.02 \mathrm{~nm}, 18.98$ and $18.90 \mathrm{~nm}$ respectively.

\subsection{SEM and EDX analysis of $\mathrm{ZnO}$ nanoparticles, $\mathrm{ZnO}-\mathrm{Ag}$ and $\mathrm{ZnO}$-Cu nanocomposites}

The morphological feature and the elemental composition of the nanomaterials synthesised were investigated using SEM equipped with an EDX as shown in Fig. 5. The SEM picture of $\mathrm{ZnO}$ nanoparticles confirmed the formation of nanoparticles with approximate nodular like shape. There was no significant change in the morphology upon the addition of Ag dopant but with the addition of $\mathrm{Cu}$ impurities, the nodular like shape aggregated into larger particles with pores but no well-defined morphology. This aggregation may be due to the presence of secondary metabolites in the leaf extracts [39] as confirmed by the $\mathrm{XRD}$. The presence of $\mathrm{Zn}, \mathrm{O}, \mathrm{Ag}$ and $\mathrm{Cu}$ were confirmed by EDX Fig. 5(a1-c1).

A strong peak for $\mathrm{O}$ appeared at about $0.5 \mathrm{keV}$ with $\mathrm{Zn}^{2+}$ ion on $1.08 \mathrm{keV}, 8.59 \mathrm{keV}$ and $9.82 \mathrm{keV} . \mathrm{Ag}^{2+}$ is at $3.09 \mathrm{keV}$ and $\mathrm{Cu}^{2+}$ peak appeared on binding energy $8.1 \mathrm{keV}$. A strong signal of $O$ on the EDXs of the synthesized nanomaterials, is partly contributed by $X$-ray emission from the phytochemicals of the dye.

\subsection{TEM and SAED pattern of the materials}

The TEM images in Fig. 6 give detailed structural analysis of the synthesized materials. The image (Fig. 6a shows the presence of nanorods coexisting with nanoflakes in $\mathrm{ZnO}$ nanoparticles. Image of $\mathrm{ZnO}-\mathrm{Ag}$ in Fig. $6 \mathrm{~b}$ revealed a polyhedral shape of $\mathrm{ZnO}$ with $\mathrm{Ag}$ dots on the surface 
Fig. 5 SEM images of a $\mathrm{ZnO}$ nanoparticles, b ZnO-Ag nanocomposite, c $\mathrm{ZnO}-\mathrm{Cu}$ nanoparticles and the EDX of (a1) ZnO nanoparticles (b1) ZnO-Ag nanocomposite (c1) ZnO-Cu nanocomposites
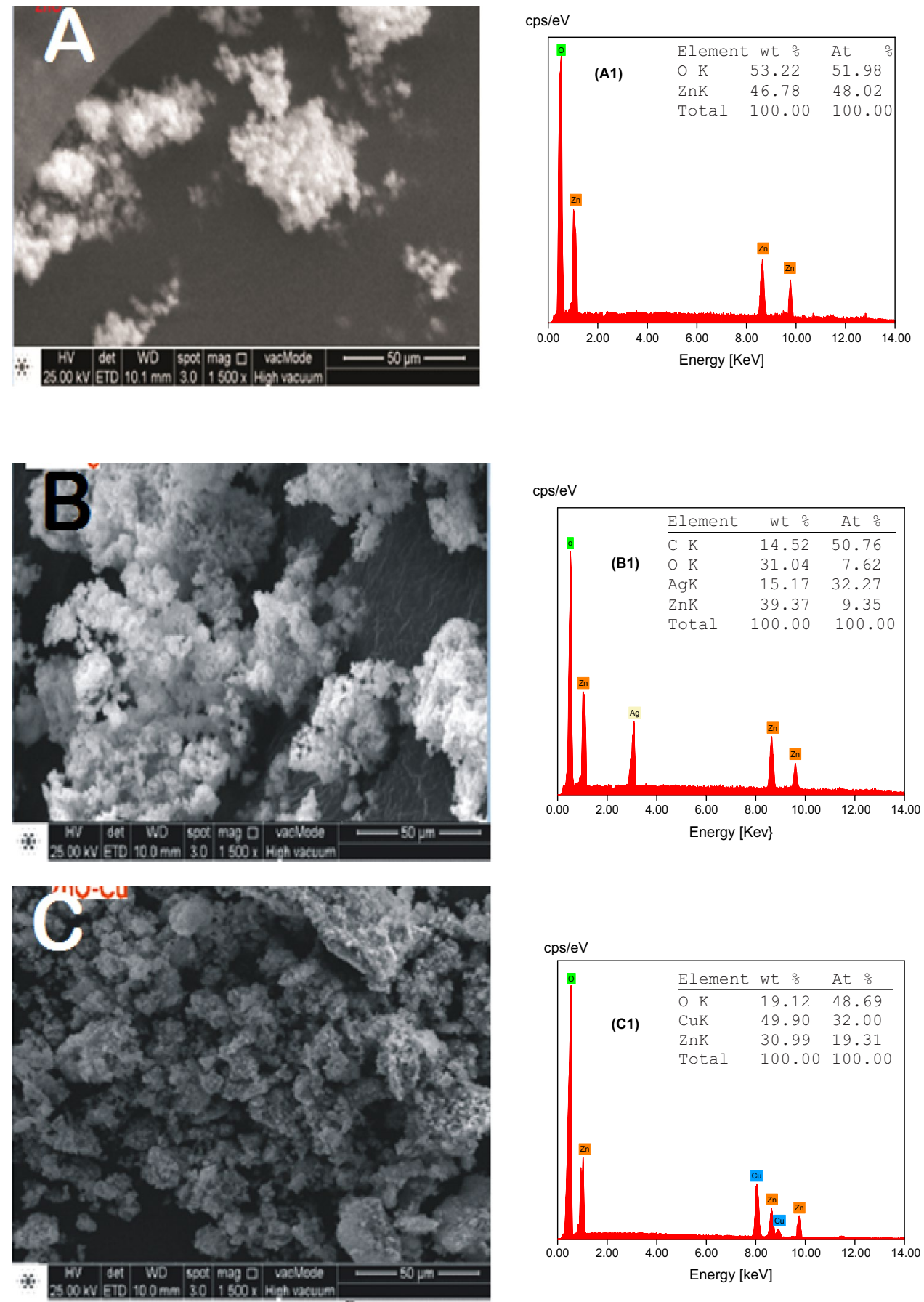

of the metrics. The introduction of $\mathrm{Cu}$ impurities to form $\mathrm{ZnO}-\mathrm{Cu}$ nanopcomposite, changed the nanorods and the flakes in $\mathrm{ZnO}$ to a spherical shape as shown in Fig. 6c. The close link between $\mathrm{Ag}$ and $\mathrm{ZnO}$ makes a strong electronic interaction that will improve the charge separation [55], this accounts for its low energy band gap when compared with $\mathrm{ZnO}-\mathrm{Cu}$ nanocomposite. The average particle sizes of $\mathrm{ZnO}, \mathrm{ZnO}-\mathrm{Ag}$ and $\mathrm{ZnO}-\mathrm{Cu}$ which are
$<50 \mathrm{~nm}$ are in consonance with XRD results. The selected area SAED pattern in Fig. 6(a2-c2) show distinct bright centric ring with further ring in Fig. 6(a2) being partially illuminated confirming the irregular orientation of its nanocrystals unlike in Fig. $6(\mathrm{~b} 2, \mathrm{c} 2)$ which indicated a regular orientation of nanocrystals [41]. 
Fig. 6 TEM Image of a $\mathrm{ZnO}$, b $\mathrm{ZnO}-\mathrm{Ag}$ and $\mathbf{c} \mathrm{ZnO}-\mathrm{Cu}$ and SEAD Image of (2a) $\mathrm{ZnO}$ nanoparticles, (2b) $\mathrm{ZnO}-\mathrm{Ag}$ nanocomposite, (2c) $\mathrm{ZnO}-\mathrm{Cu}$ nanocomposite
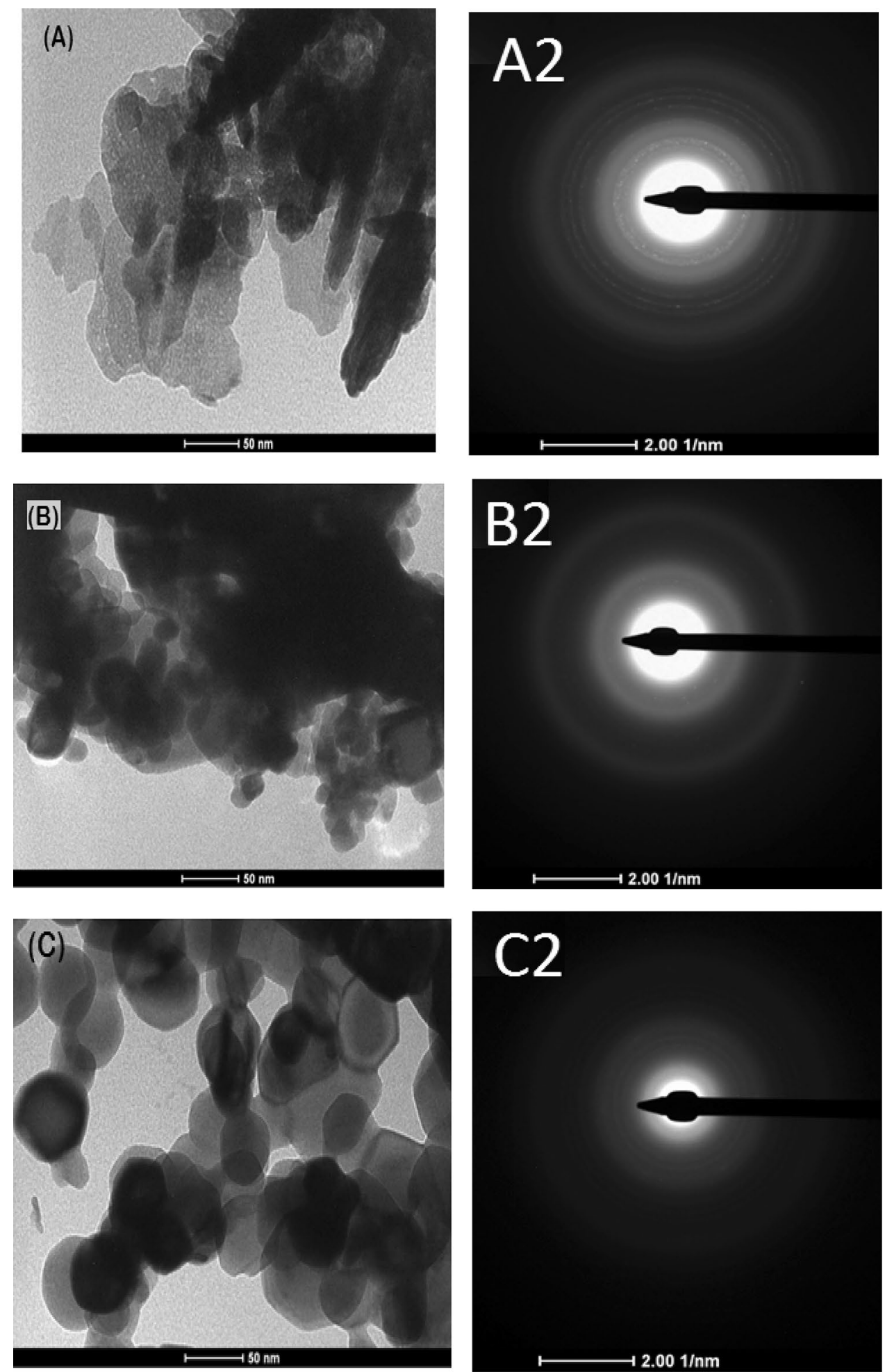

\section{Conclusion}

Nanoparticles and nanocomposites were effectively synthesized by a green method using Soxhlet extracted dye of $B$. ferruginea as a reducing and capping agent. $\mathrm{O}-\mathrm{H}, \mathrm{C}=\mathrm{O}$, $\mathrm{N}-\mathrm{H}, \mathrm{C}-\mathrm{O}$ and $\mathrm{S}=\mathrm{O}$ were ascertained to be the functional groups that, were involved in the reduction and stabilizing of the nano ions. The optical studies revealed a narrowing of band gap from 3.24 to $3.13 \mathrm{eV}$ as $\mathrm{Ag}^{2+}$ and $\mathrm{Cu}^{2+}$ gradually substituted the $\mathrm{Zn}^{2+}$ ions in the $\mathrm{ZnO}$ matrix. High level of crystallinity and the average crystallite size of $19.02,18.98$ and $18.90 \mathrm{~nm}$ was recorded for $\mathrm{ZnO}, \mathrm{ZnO}-\mathrm{Ag}$ 
and $\mathrm{ZnO}-\mathrm{Cu}$ respectively. SEM and TEM analysis clearly indicated the formation of flakes with nanorods for $\mathrm{ZnO}$, polyhedral shape with Ag dots and spherical shape upon doping of $\mathrm{ZnO}$ with $\mathrm{Ag}$ or $\mathrm{Cu}$. The elemental analysis confirmed peaks for $\mathrm{Zn}, \mathrm{Ag}, \mathrm{Cu}$ and $\mathrm{O}$. The bright centric ring and other non-luminous ring of the SAED revealed an irregular orientation. These findings inferred the viability of the dye extracted from $B$. ferruginea as a reducing and capping agent capable of synthesizing nanoparticles and nanocomposites that are eco-friendly with potentials in photovoltaic, electronics and photocatalytic applications.

\section{Compliance with ethical standard}

Conflict of interest The authors declare no conflicts of interest

\section{References}

1. Firdhouse MJ, Lalitha P (2015) Biosynthesis of silver nanoparticles and its applications. Rev J Nanotechnol. https://doi. org/10.1155/2015/829526

2. Khana SA, Noreenb F, Kanwalc S, lqbald A, Hussaine G (2018) Green synthesis of $\mathrm{ZnO}$ and $\mathrm{Cu}$-doped $\mathrm{ZnO}$ nanoparticles from leaf extracts of Abutilon indicum, Clerodendrum infortunatum, Clerodendrum inerme and investigation of their biological and photocatalytic activities. Mater Sci Eng 82:46-59

3. Kim JB, Byun D, le SY, Park DH, Choi WK, Choi JW, Angadi B (2008) $\mathrm{Cu}$-dope $\mathrm{ZnO}$ - based $\mathrm{p}-\mathrm{n}$ hetero-junction light emitting diode. Semicond Sci Technol 23(9):095004-095010

4. Oscar, FL, Vismaya S, Arunkumar M, Thajuddin N, Dhanasekaran D, Nithya C (2016) Algal nanoparticles: synthesis and biotechnological potentials. World's largest Science, Technology \& Medicine Publisher INTECH, pp 157-182

5. Kumar J, Shrivastava V, Thakur S (2013) Synthesis and characterization of silver doped zinc oxide nanoparticles and their antifungal activity against aspergillus brasiliensi and candida albicans. Adv Sci Focus 1:346-350

6. Chen S, Zhao X, Xie H, Liu J, Duan L, Ba X, Zhao J (2012) Photoluminescence of undoped and $\mathrm{Ce}$-doped $\mathrm{SnO} 2$ thin films deposited by sol-gel-dip-coating method. Appl Surf Sci 258:32553259. https://doi.org/10.1016/j.apsusc.20011.11.077

7. Vijayakumar TS, Karthikeyeni S, Vasanth S, Ganesh A, Bupesh G, Ramesh G, Manimegalai M, Subramania P (2013) Synthesis of silver-doped zinc oxide nanocomposite by pulse mode ultrasonication and its characterization studies. J Nanosci. https:// doi.org/10.1155/2013/785064

8. Sathyavathi R, Krishna MB, Rao SMJ, Saritha R, Rao DN (2010) Biosynthesis of silver nanoparticles using coriandrum sativum leaf extract and their application in nonlinear optics. Adv Sci Lett 3:1-6

9. Kumar S, Malodia CL (2017) Biosynthesis of zinc oxide nanoparticles using leaf extract of Calotropis gigantea: characterization and its evaluation on tree seedling growth in nursery stage. Appl Nanosci 7:501-512

10. Brayner R, ferarri-lliou R, Brivois N, Djediat S, Benedetti MF, levet F (2006) Toxicological impact studies based on Escherichia coli bacteria in ultrafine $\mathrm{ZnO}$ nanoparticle colloidal medium. Nano Lett 6(4):866-870
11. Tin S, Sakharkar KR, Lim CS, Sakharkar MK (2009) Activity of Chitosan in combination with antibiotics in Pseudomonas aeruginosa. Int J Biol Sci 5(2):153-160

12. Schubert EF (2005) Doping in III-V semiconductors, Cambridge studies in semiconductor physics and microelectronic engineering, 1st edn. Cambridge University Press, Cambridge

13. Zhang $X$, Song $H$, Yu L, Wang $T$, Ren $X$, Kong $X$, Xie $Y$, Wang $X$ (2006) Surface states and its influence on luminescence in ZnS nanocrystallites. J Lumin 118:251-256

14. Rekha K, Nirmala M, Nair MG, Anukaliani A (2010) Structure, optical, photocatalytic and antibacterial activity of zinc oxide and manganese doped zinc oxide nanoparticles. Phys B 405:3180-3185

15. Qiao SZ, Liu J, Qing G, Lu M (2011) Synthetic chemistry of nanomaterials. In: Modern inorganic synthetic chemistry. Elsevier, New York, pp 479-506

16. Phoohinkong W, Foophow T, Pecharapa W (2017) Synthesis and characterization of copper zinc oxide nanoparticles obtained via metathesis process. Adv Nat Sci Nanosci Nanotechnol. https://doi.org/10.1088/2043-6254/aa7223

17. Fu D, Han G, Chang Y, Dong J (2012) Synthesis and properties of $\mathrm{ZnO}$-graphene nano hybrid for photodegradation of organic pollutant in water. Mater Chem Phys 132(2012):673-681

18. Wang $X$, Ding Y, Summers CJ, Wang ZL (2004) Large cale synthesis of $6 \mathrm{~nm}$ wide $\mathrm{ZnO}$ nanobelts. J Phys Chem 26:8773-8777

19. Ramimoghadam D, Bagheri S, Hamid SBA (2014) Biotemplated synthesis of anatase titanium dioxide nanoparticles via lignocellulosic waste material. Biomed Res Int. https://doi. org/10.1155/2014/205636

20. Sharma D, Rajput J, Kaith BS, Kaur M, Sharma S (2010) Synthesis of $\mathrm{ZnO}$ nanoparticles and study of their antibacterial and antfungal properties. Thin Solid File 519:1224-1229

21. Liu W, Cui Y, Zhang L, Ren S (2009) Study on extracting natural plant dyestuff by enzyme-ultrasonic method and its dyeing ability. J Fiber Bioeng Inf 2(1):21-30

22. Deveog O, Torganc E, Karadag R (2011) High-performance liquid chromatography of some natural dyes: analysis of plant extracts and dyed textiles. Color Technol 128:133-138

23. Rashid MA, Gustafson KR, Cardellina JH, Boyd MR (2001) A new Podophyllojoxin derivative from Bridelia ferruginea. Nat Prod Lett 14:285-292

24. Orafidiya LO, Lamikanra A, Adediji JA (1990) Coagulation of milk as an index of astringency of the bark extract of Bridelia feruginea Benth. and lime juice for the formulation of a traditional gargle "Ogun Efu". Phytother Res 4:189-194

25. Cimanga K, De-Bruyne T, Apers S, Dieters L, Totte J, Kambu K, Tona L, Bakana P, Van-Ufford LQ, Beukelman C, Labadie R, Vlietinck AJ (1999) Complement- inhibiting constituents of Bridelia ferruginea stem bark. Planta Med 65:213-217

26. Olarewaju O, Oloyede O, Ojo O, Onikanni A, Ajiboye B (2014) In-vitro antioxidant activities of the stem bark extract fractions of Bridelia ferruginea. J Biol Agric Healthc 4(3):1-7

27. Yedurkar S, Maurya C, Mahanwar P (2016) Biosynthesis of zinc oxide nanoparticles using ixora coccinea leaf extract-a green approach. Open J Synth Theory Appl 5:1-14. https://doi. org/10.4236/ojsta.2016.51001Y

28. Mohammed MA, Abu-Taleb A, Remalli N, Abdullah M, Srikanth Vadali SVSS, Labhasetwa NK (2013) Dragon's blood aided synthesis of $\mathrm{Ag} / \mathrm{Ag} 2 \mathrm{O}$ core/shell nanostructures and $\mathrm{Ag} / \mathrm{Ag} 2 \mathrm{O}$ decked multi-layered graphene for efficient As(III) uptake from water and antibacterial activity. RSC Adv. https://doi. org/10.1039/c6ra05061aa

29. Ahmad A, Li B, Khan AU, shah SAA, khan GM, Khan ZUH, Khan Q, Khan FU (2016) Biodirected Synthesis of Palladium nanoparticles using Phoenix dactylifera leaves extract and their size 
dependent biomedical and catalytic applications. RSC Adv. https://doi.org/10.1039/c6ra11409a

30. Hong $\mathrm{H}$, Chen HB, Yang DH, Shang MY, Wang X, Cai SQ, Mikage $M$ (2011) Comparison of content of five ephedrine alkaloids in three official origin of Ephedra Herb in China by high-performance liquid chromatography. J Nat Med 65:623-628. https:// doi.org/10.1007/s11418-011-0528-8

31. Gul R, Jan SU, Farklullah S, Sherani S, Jahan N (2017) Preliminary phytochemical screening, quanntitative analysis of alkaloid and antioxidant activity of crude plant extracts from Ephedra Intermedia Indigenous to Balochistan. Sci Word J. https://doi. org/10.1155/2017/5873648

32. Jamous R, Zaitoun S, Husein A, Qasem I, Ali-Shtayeh M (2015) Screening for biology activities of medicinal plants used in traditional Arabic Palestinian herbal medicine. Eur J Med plant 9:1-13

33. Karande AM, Kamble HV, Kumbhar VH, Kane SR, Magdum CS (2016) Preliminary phytochemical screening of Glochidion ellipticum. Eur J Exp Biol 6(4):41-45

34. Ezeonu SC, Ejikeme CM (2016) Qualitative and quantitative determination of phytochemical contents of indigenous Nigerian softwoods. New J Sci. https://doi.org/10.1155/2015/

35. Vanaja M, Annadurai G (2013) Coleus aromaticus leaf extract mediated synthesis of silver nanoparticles and its bactericidal activity Applied. Nanoscience 3:217-223. https://doi. org/10.1007/s13204-012-0121-9

36. Mphande BC, Pogrebnoi A (2014) Impact of extraction methods upon light absorbance of natural organic dyes for dye sensitized solar cells application. J Energy Nat Res 3(3):38-45

37. Lattanzio V, Lattanzio VMT, Cardinali A (2006) Role of phenolics in the resistance mechanisms of plants against fungal pathogens and insects. In: Imperato F (ed) Phytochemistry: advances in research. Research Signpost, Thiruvananthapuram, pp 23-67

38. Selim KA, Khalil KE, Abdel-Bary MS, Abdel-Azeim NA (2008) Extraction, Encapsulation and utilization of red pigments from roselle (Hibiscus sabdariffa L.) as natural food colourants. Special Volume Conference, Alex J Food Sci Technol 7-20

39. Prasad R, Swamy VS (2013) Antibacterial activity of silver nanoparticles synthesized by Bark Extract of Syzygium cumini. J Nanopart. https://doi.org/10.1155/2013/431218

40. Awwad AN, Salem NM, Abdeen AO (2013) Green synthesis of silver nanoparticles using carob leaf extract and its antibacterial activity. Int J Ind Chem 4(1):29. https://doi. org/10.1186/2228-5547-4-29

41. Talam S, Karumuri SR, Gunnam N (2012) Synthesis, characterization, and spectroscopic properties of $\mathrm{ZnO}$ nanoparticles. Nanotechnology. https://doi.org/10.5402/2012/372505

42. Varadavenkatesan T, Lyubchik E, Pai S, Pugazhendhi A, Vinayagam R, Selvaraj R (2019) Photocatalytic degradation of Rhodamine $B$ by zinc oxide nanoparticles synthesized using the leaf extract of Cyanometra ramiflora. J Photochem Photobiol B Photobiol B Biol 199:111621

43. Shraddha P, Sridevi H, Thivaharan V, Ramesh V, Raja S (2019) Photocatalytic zinc oxide nanoparticles synthesis using Peltophorum pterocarpum leaf extract and their characterization. Optik Int J Light Electron Optics 185:248-255. https://doi.org/10.1016/j. ijleo.2019.03.101

44. Kumar B, Smita K, Cumbal L, Debut A (2017) Green synthesis of silver nanoparticles using Andean blackberry fruit extract. Saudi J Biol Sci 24(1):45-50. https://doi.org/10.1016/j.sjbs.2015.09.006

45. Omotunde Ol, Okoronkwo AE, Aiyesanm AF, Gurgur E (2018) Photocatalytic behavior of mixed oxide $\mathrm{NiO} / \mathrm{PdO}$ nanoparticles toward degradation of methyl red in water. J Photochem Photobiol A 365:145-150

46. Yusof AS, Hassan Z (2018) Fabrication and characterization of Cu-doped $\mathrm{ZnO}$ films using RF reactive magnetron sputtering. J Phys. https://doi.org/10.1088/1742-6596/1083/1/012062

47. Lim SP, Pandikumar A, Lim HN, Ramaraj R, Huang NM (2015) Boosting photovoltaic performance of dyesensitized solar cells using silver nanoparticle-decorated N, S-Co-doped-TiO2 photoanode. Sci Rep 5:11922. https://doi.org/10.1038/srep11922

48. Ghosh A, Kumari N, Bhattacharjee A (2015) Influence of Cu doping on structural, electrical and optical properties of $\mathrm{ZnO}$. Pramana 84(4):621-635

49. Zhou J, Zhao F, Wang Y, Zhang Y, Yang L (2007) Size controlled synthesis of $\mathrm{ZnO}$ nanoparticles and their photoluminescence properties. J Lumin 122-123(1-2):195-197

50. Khoshhesab Z, Sarfaraz M, Asadabad MA (2011) Preparation of $\mathrm{ZnO}$ nanostructures by chemical precipitation method. Synth React Inorg Met Org Chem 41:814-819

51. JCPDS, Powder Diffraction File, Alphabetical Index, Inorganic Compounds, International Centre for Diffraction Data, Newtown Square, Pa, USA (1977)

52. Dinesha VP, Bijia P, Ashoka A, Dharab SK, Kamaruddinb M, Tyagib AK, Raja B (2014) Plasmon-mediated highly enhanced photocatalytic degradation of industrial textile effluent dyes using hybrid ZnO@Ag Core-shell Nanorods. RSC Adv 4:58930-58940. https://doi.org/10.1039/C4RA09405K

53. Singh R, Barman PB, Sharma D (2017) Synthesis, structural and optical properties of $\mathrm{Ag}$ doped $\mathrm{ZnO}$ nanoparticles with enhanced photocatalytic properties by photo degradation of organic dyes. J Mater Sci Mater Electron 28:5705-5717

54. Mukhtar M, Munisa L, Saleh R (2012) Co-precipitation of synthesis and characterization of nanocrystalline zinc oxide particles dope with Cu2 + ions. Mater Sci Appl 3(8):543-551. https://doi. org/10.4236/msa.2012.3807

55. Mashwani Z, Khan MA, Khan T, Nadhman A (2016) Applications of plant terpenoids in the synthesis of colloidal silver nanoparticles. Adv Colloid interface Sci 234:134-141. https://doi. org/10.1016/j.cis.2016.04.008

Publisher's Note Springer Nature remains neutral with regard to jurisdictional claims in published maps and institutional affiliations. 